\title{
IKLIM BELAJAR SEBAGAI PENDUKUNG PENERAPAN MODEL PEMBELAJARAN JATIDIRI BANGSA
}

\author{
${ }^{1}$ Yogi Nugraha \\ ${ }^{1}$ Dosen Pendidikan Pancasila dan Kewarganegaraan \\ Fakultas Keguruan dan Ilmu Pendidikan \\ Universitas Buana Perjuangan Karawang \\ Email: yogi.nugraha@ubpkarawang.ac.id
}

\begin{abstract}
Learning atmosphere needs to be formed in a proper to learn in order to make the students feel comfortable in their studies. This research using the method of literature or also known as the study of texts. The nation's identity in this study paid attention to the Pancasila as an estuary or goals. Identity of the nation based on Pancasila is the character or personality of the Indonesian people whose attitudes and behavior reflect the value of God (religious), Humanity (human), Unity (nationalist), Democracy (democratic) and Justice (fair) so that the attitude and the behavior show our identity as a nation and then bring our uniqueness when dealing with other state.
\end{abstract}

Keywords: learning atmosphere, learning model, national identity

\begin{abstract}
ABSTRAK
Iklim belajar perlu dibentuk dalam suasana yang layak untuk belajar agar membuat mahasiswa merasa nyaman dalam menuntut ilmu. Penelitian ini menggunakan metode studi pustaka atau disebut juga studi teks. Jatidiri bangsa dalam penelitian ini mengarahkan perhatiannya pada Pancasila sebagai muara atau goalsnya. Jatidiri bangsa berdasarkan Pancasila adalah karakter atau kepribadian manusia Indonesia yang sikap dan perilakunya mencerminkan nilai KeTuhanan (religius), Kemanusiaan (manusiawi), Persatuan (nasionalis), Kerakyatan (demokratis) dan Keadilan (adil) sehingga dengan sikap dan perilaku tersebut menunjukkan identitas kita sebagai sebuah bangsa dan selanjutnya memunculkan keunikan kita manakala berhubungan dengan bangsa lain.
\end{abstract}

Kata kunci: iklim belajar, model pembelajaran, jatidiri bangsa.

\section{PENDAHULUAN}

Efektifitas pelaksanaan

pembelajaran dipengaruhi oleh beberapa faktor. Salah satu faktor yang menjadi pengaruh dalam kesuksesan pembelajaran adalah suasana belajar itu diciptakan dengan senyaman mungkin. Pelaksanaan pembelajaran adalah salah satu upaya dalam melaksanakan sebuah bentuk pendidikan. Cogan (1998:11) menyatakan bahwa Citizenship Education "...future educational policy must be based upon a conception of what we describe as multidimensional citizenship".

Pernyataan tersebut mengartikan bahwa kebijakan pendidikan di masa mendatang harus didasarkan pada konsepsi apa yang kita gambarkan sebagai kewarganegaraan multidimensional. Dengan kata lain, pendidikan kewarganegaraan pada masa mendatang tidak hanya menjadi pelajaran yang dibelajarkan di sekolah-sekolah, akan tetapi menjadi tindakan nyata di masyarakat dan 
dapat dipraktekkan dengan baik oleh seluruh masyarakat dengan menyentuh aspek-aspek multidimensinya.

Suasana belajar atau disebut juga iklim belajar ataupun atmosfer belajar merupakan sebuah hal yang sangat penting dibalik suksesnya sebuah pembelajaran dilaksanakan. Iklim belajar perlu dibentuk dalam suasana yang layak untuk belajar agar membuat pebelajar merasa nyaman dalam menuntut ilmu dan mengembangkan keilmuannya. Iklim belajar yang nyaman perlu dibentuk oleh seluruh lapisan yang terkait dalam pendidikan. Iklim belajar perlu dibentuk dalam suasana yang layak untuk belajar agar membuat mahasiswa merasa nyaman dalam menuntut ilmu. Iklim belajar yang nyaman dapat diwujudkan dalam berbagai kegiatan yang ada di kampus. Berbagai kegiatan di kampus dapat dikatakan melatih kecintaan mahasiswa terhadap negaranya.

Proses pendidikan tidak akan terjadi dengan sendirinya melainkan harus direncanakan, diprogram, dan difasilitasi dengan dukungan dan partisipasi aktif dosen sebagai pendidik. Tugas dan tanggung jawab dosen adalah mengubah perilaku mahasiswa ke arah pencapaian tujuan pendidikan. Oleh karena itu, pencapaian tujuan pendidikan sangat bergantung kepada pelaksanaan tugas dan kinerja dosen disamping kemampuan mahasiswa itu sendiri serta dukungan komponen sistem pendidikan lainnya.

Posisi strategis dosen merupakan salah satu faktor penentu kualitas proses dan hasil pendidikan. Pencapaian tujuan pendidikan akan ditentukan oleh sejauh mana kesiapan dosen dalam mengarahkan mahasiswanya melalui kegiatan pembelajaran. Ketika pembelajaran berlangsung, dosen tidak sekedar menyampaikan pelajaran akan tetapi juga menciptakan suasana belajar atau iklim belajar nyaman yang dialami setiap mahasiswa. Komunikasi antara dosen dan mahasiswa sebaiknya berjalan dengan lancar. Suasana seperti ini sangat dibutuhkan mahasiswa sehingga kelas menjadi tempat yang menyenangkan dan mahasiswa lebih mudah memahami pelajaran. Kemudian ketauladanan dosen merupakan salah satu yang harus ditunjukan terhadap mahasiswa agar menjadi salah satu acuan mahasiswa dalam berperilaku baik dan disiplin. Dalam hal ini dosen harus menunjukkannya dalam proses pembelajaran maupun diluar proses pembelajaran dalam lingkungan sekolah.

Dewasa ini banyak ditemukan perilaku-perilaku yang tidak mencerminkan kepribadian bangsa Indonesia. Praktek-praktek perilaku menyimpang yang terjadi di sebuah negara, merupakan pangkal dari kurangnya rasa kecintaan terhadap Indonesia dan rasa kecintaan terhadap Indonesia. Kurangnya rasa persatuan dan kesatuan serta kurangnya saling menghargai antar sesama bangsa Indonesia perlu menjadi perhatian bagi kita semua. Praktek-praktek saling mengagungkan dan menganggap diri sendiri atau golongannya paling benar mulai merebak di bumi Indonesia.

Persoalan tersebut membuat kita seakan lupa akan jatidiri bangsa Indonesia yang memang terlahir dalam berbagai macam keberagaman. Hal ini juga mulai menjangkiti mahasiswa yang seharusnya menjadi pelopor bangkitnya kembali rasa kecintaan terhadap Indonesia. Maka 
diperlukan sebuah usaha untuk kembali mengingatkan semua lapisan elemen bangsa untuk saling menghargai dan menghormati perbedaan yang ada di Indonesia. Semangat kebangsaan yang harus dijunjung tinggi, bukan malah semangat mengobarkan perbedaan yang ada yang pada ujungnya nanti membawa perpecahan bagi bangsa Indonesia. Model pembelajaran jatidiri bangsa mencoba mengembalikan rasa kecintaan terhadap Indonesia yang jauh ditinggalkan oleh mahasiswa yang telah tergerus seiring perkembangan jaman. Hal ini merupakan upaya untuk megingatkan kembali mahasiswa pada jatidiri bangsa Indonesia.

Model pembelajaran Jatidiri Bangsa merupakan sebuah usaha menghidupkan kembali nilai-nilai kecintaan terhadap Indonesia yang semakin luntur dalam diri mahasiswa. Semuanya dilakukan dalam rangka implementasi terhadap aspek pengetahuan warganegara (civic knowledge), dan keterampilan warganegara (civic skills). Implementasi pengetahuan warganegara (civic knowledge) dan keteramilan warganegara (civic skills) merupakan aspek yang harus dimiliki oleh warganegara. Konteks ini tentu saja bagaimana pendidikan kewargangeraan mengambil peran atas implementasi kedua aspek tersebut.

Ada banyak pengertian Pendidikan Kewarganegaraan yang dijelaskan oleh beberapa pakar pendidikan. Sebelum menemukan pengertian Pendidikan Kewarganegaraan yang sesungguhnya, marilah kita sedikit memahami asal-usul Pendidikan Kewarganegaraan. Pendidikan
Kewarganegaraan menurut Cox dalam Sapriya (2011) awalnya diperkenalkan di Amerika Serikat pada tahun 1870 dengan tujuan untuk meng-Amerika-kan bangsa Amerika dengan nama "Civics".

Sedangkan di Indonesia, istilah civics dan civics education telah muncul pada tahun 1957, dengan istilah Kewarganegaraan, Civics pada tahun 1961 dan Pendidikan Kewargaan Negara pada tahun 1968. (Maftuh dan Sapriya dalam Civicus, 2005). Mata pelajaran pendidikan kewarganegaraan masuk dalam kurikulum sekolah pada tahun 1968, namun pada tahun 1975 nama pendidikan kewarganegaraan berubah menjadi Pendidikan Moral Pancasila (PMP). Pada tahun 1994, PMP berubah kembali menjadi Pendidikan Pancasila dan Kewarganegaraan (PPKn).

Menurut Azyumardi Azra dalam Aulia (2012), pendidikan kewarganegaraan, civics education dikembangkan menjadi pendidikan kewargaan yang secara substantif tidak saja mendidik generasi muda menjadi warga negara yang cerdas dan sadar akan hak dan kewajibannya dalam konteks kehidupan bermasyarakat dan bernegara, tetapi juga membangun kesiapan warga negara menjadi warga dunia, global society. Hal ini diperkuat oleh pernyataan Edmonson dalam Aulia (2012) yang mengemukakan bahwa civics adalah kajian yang berkaitan dengan pemerintahan dan yang menyangkut hak dan kewajiban warga negara.

Henry Randall Waite dalam Aulia (2012) merumuskan pengertian Civics dengan "The science of citizenship, the relation of man, the individual, to man in organized collection, the individual in his 
relation to the state". Dari pengertian tersebut dapat kita simpulkan bahwa ilmu Kewarganegaraan membicarakan hubungan antara manusia dengan manusia dalam perkumpulan perkumpulan yang terorganisasi (organisasi social ekonomi, politik) dengan individuindividu dan dengan negara.

Dari penjelasan para pakar di atas dapat kita simpulkan bahwa pendidikan kewarganegaraan adalah upaya sadar dan terencana untuk mencerdaskan kehidupan bangsa bagi warga negara dengan menumbuhkan jati diri dan moral bangsa sebagai landasan pelaksanaan hak dan kewajiban dalam bela negara, demi kelangsungan kehidupan dan kejayaan bangsa dan negara. Menurut beberapa sumber, dalam konteks Ilmu Pengetahuan Sosial, PKn sering dikatakan sebagai suatu mata pelajaran yang mempunyai keterkaitan dengan Pendidikan Ilmu Pengetahuan Sosial. Pendidikan Kewarganegaraan mempunyai peran yang sangat strategis dalam membangun karakter warganegara (Sapriya, 2011:96). Menurut buku Teori Dan Landasan Pendidikan Kewarganegaraan yang ditulis oleh Sapriya dan Wahab (2011), dikatakan bahwa PKn merupakan suatu bidang kajian yang bersifat multifacet dengan bidang ilmu lainnya. Secara metodologis, PKn merupakan pengembangan salah satu dari lima tradisi Social Studies.

PKn merupakan bagian atau usaha salah satu tujuan Pendidikan IPS (Social Science Education) yaitu bahan pendidikannya diorganisir secara terpadu (integrated) dari berbagai disiplin ilmu-ilmu sosial, humaniora, dokumen negara, terutama Pancasila, UUD 1945, dan perundangan negara, dengan tekanan bahan pendidikan pada hubungan warga negara dan yang berkenaan dengan bela negara. Dikatakan oleh Jarolimek dan Parker dalam Sapriya (2011:99) bidang studi yang mempunyai tanggung jawab khusus terhadap PKn adalah Social Studies (Ilmu Pengetahuan Sosial). Pada dasarnya Ilmu Pengetahuan Sosial telah banyak berperan dalam penyelenggaraan $\mathrm{PKn}$ dalam membentuk karakter warga negara yang baik.

Dari beberapa pandangan mengenai PKn dalam konteks Ilmu Pengetahuan Sosial tersebut di atas, dapat disimpulkan bahwa PKn merupakan sasaran inti yang dikembangkan dalam Pendidikan Ilmu Pendidikan Sosial (Sapriya, 2011:99). Sebagai suatu bidang studi yang membangun kemahiran intelektual warga negara dengan pengetahuan-pengetahuan yang diajarkannya, PKn juga mempunyai tujuan besar yaitu membentuk warga negara yang baik. Sesuai dengan tujuannya, Pendidikan Kewarganegaraan mempunyai tujuan mulia yaitu membentuk karakter warga negara yang baik yang sesuai dengan Pancasila dan UUD NRI 1945. Oleh karena itu, eksistensinya dalam dunia pendidikan di Indonesia patut mendapat perhatian lebih.

Begitu pentingnya Pendidikan Kewarganegaraan dalam dunia pendidikan di Indonesia diperkuat keberadaannya dengan menetapkan Pendidikan Kewarganegaraan sebagai salah satu mata pelajaran wajib dalam kurikulum pendidikan dasar, pendidikan menengah, dan pendidikan tinggi (Pasal 37 UU No. 20 tahun 2003). PKn merupakan usaha untuk membekali peserta didik dengan pengetahuan dan kemampuan dasar berkenaan dengan hubungan 
antara warga negara dengan negara serta pendidikan pendahuluan bela negara agar menjadi warga negara yang dapat diandalkan oleh bangsa dan negara.

Pendidikan Kewarganegaraan bertujuan untuk membekali para peserta didik dengan pengetahuan dan kemampuan dasar termasuk karakter didalamnya agar dapat diandalkan oleh bangsa dan negara. Mata pelajaran PKn juga merupakan program pendidikan yang berintikan demokrasi politik yang diperluas dengan sumber-sumber pengetahuan lainnya, pengaruh-pengaruh positif dari pendidikan sekolah, masyarakat dan orang tua, yang kesemuanya itu diproses guna melatih para siswa untuk berfikir kritis, analitis, bersikap dan bertindak demokratis dalam mempersiapkan hidup demokratis yang berdasarkan Pancasila dan UUD NRI 1945 (Somantri, 2001)

Dengan demikian, Pendidikan Kewarganegaraan merupakan satu mata pelajaran yang sangat penting dalam pembentukan karakter manusia Indonesia yang sangat beragam sesuai Pancasila dan Undang-Undang dasar NRI 1945. Berdasarkan penjelasan di atas dikatakan bahwa Pendidikan Kewarganegaraan adalah kajian keilmuan yang memiliki tiga ciri khas yaitu pengetahuan, keterampilan, dan pembentukan karakter warga negara.

Pendapat lain menurut Maftuh dan Sapriya (2005:321) menjelaskan bahwa Pendidikan Kewarganegaraan yaitu:

Mata pelajaran Pendidikan Kewarganegaraan adalah program pendidikan atau mata pelajaran yang memiliki tujuan utama untuk mendidik siswa agar menjadi warga negara yang baik, demokratis dan bertanggung jawab. Program
Pendidikan Kewarganegaraan ini memandang siswa dalam kedudukannya sebagai warga negara, sehingga programprogram, kompetensi atau materi yang diberikan kepada peserta didik diarahkan untuk mempersiapkan mereka mampu hidup secara fungsional sebagai warga masyarakat dan warga negara yang baik.

Berdasarkan penjelasan di atas, pendidikan kewarganegaraan merupakan mata pelajaran yang memberikan bekal kepada peserta didik untuk meningkatkan kecerdasan multidimensional untuk membentuk warga negara yang baik (to be good citizenship) yang memiliki pengetahuan, keterampilan, dan karakter untuk membangun keberlangsungan kehidupan berbangsa dan bernegara.

Pendidikan Kewarganegaraan mengarahkan perhatian pada moral yang diharapkan yang dapat diwujudkan dalam kehidupan seharihari. Perilaku yang memancarkan iman dan taqwa terhadap Tuhan Yang Maha Esa dalam masyarakat yang terdiri dari berbagai golongan agama, perilaku yang bersifat kemanusiaan yang adil dan beradab, perilaku yang mendukung persatuan bangsa dalam masyarakat yang beranekaragam kebudayaan dan kepentingan, perilaku yang mendukung kerakyatan yang mengutamakan kepentingan bersama di atas kepentingan perorangan dan golongan. Sehingga perbedaan pemikiran, pendapat ataupun kepentingan diatasi melalui musyawarah dan mufakat, serta perilaku yang mendukung upaya untuk mewujudkan keadilan sosial bagi seluruh rakyat Indonesia. 
Pendidikan Kewarganegaraan juga merupakan mata pelajaran yang memberikan bekal kepada peserta didik mengenai pengetahuan dan kemampuan dasar yang berkenaan dengan hubungan antar warga negara dengan negara dan pengetahuan bela negara sehingga menjadikan peserta didik menjadi warga negara yang dapat diandalkan oleh bangsa dan negara (Somantri, 2001).

Berdasarkan uraian di atas terdapat tiga ciri khas yang dimiliki mata pelajaran PKn, yakni meliputi pengetahuan, keterampilan, dan karakter kewarganegaraan. Ketiga hal tersebut merupakan bekal bagi peserta didik untuk meningkatkan kecerdasan multidimensional yang memadai untuk menjadi warga negara yang baik.

Pengimplementasian kedua
aspek didukung oleh terselenggaranya model pembelajaran yang dikembangkan yaitu model pembelajaran jatidiri bangsa. Jatidiri bangsa merupakan sesuatu hal yang penting bagi semua bangsa di dunia dalam pergaulan internasional. Jatidiri bangsa merupakan identitas bagi sebuah bangsa untuk menentukan pandangan politik luar negeri, politik dalam negeri, pondasi untuk menentukan keputusankeputusan yang pada hakikatnya untuk membangun kemakmuran dan kesejahteraan bangsa tersebut, dan menjadi keunikan bagi sebuah bangsa.

Proses pengenalan jatidiri membutuhkan pendalaman untuk mengenali apa, siapa, dimana, mengapa dan bagaimana diri kita. Begitu pun bagi sebuah bangsa, proses pengenalan jatidiri bangsa perlu dilakukan dengan berbagai macam cara. Salah satu cara yang dapat dilakukan adalah dengan pengenalan model pembelajaran jatidiri bangsa.

Model pembelajaran jatidiri bangsa mengenalkan kepada mahasiswa tentang pentingnya sejarah perjuangan bangsa Indonesia pada masa lalu, tentang banyaknya suku bangsa dan budaya, tentang Indonesia kontemporer untuk mencoba mengingatkan dan memberikan semangat kepada mahasiswa agar tumbuh rasa kecintaan terhadap Indonesia dalam dirinya.

\section{METODE}

Metode penulisan ini adalah metode studi pustaka. Studi pustaka atau disebut juga studi teks Noeng Muhadjir Penelitian ini adalah penelitian studi teks atau studi pustaka. Studi teks menurut Noeng Muhadjir (2000:297) mencakup: pertama, telaah teoritik suatu disiplin ilmu yang perlu dilanjutkan secara empirik untuk memperoleh kebenaran secara empirik pula. Kedua, studi yang berupaya mempelajari seluruh obyek penelitian secara filosofis atau teoritik dan terkait dengan validitas. Ketiga, studi yang berupaya mempelajari teoritik linguistic. Keempat, adalah studi karya sastra.

Salah satu alasan menggunakan metode ini adalah untuk memahami secara mendalam dan komprehensif tentang iklim belajar sebagai pendukung penerapan model pembelajaran jatidiri bangsa.

\section{PEMBAHASAN \\ Iklim Belajar}

Perlu dijelaskan mengenai pengertian iklim belajar sebelum kita membahas mengenai konsep iklim belajar secara mendalam. Ada beberapa istilah yang kadang-kadang digunakan secara bergantian dengan 
kata climate, yang diterjemahkan dengan iklim, seperti feel, atmosphere, tone, dan environment.

Bloom (1964) dalam Trisetiyanto (2013) mendefinisikan iklim dengan kondisi, pengaruh, dan rangsangan dari luar yang meliputi pengaruh fisik, sosial, dan intelektual yang mempengaruhi pebelajar.

Hoy dan Miskell (Trisetiyanto, 2013) yang juga dikutip oleh Tarmidi (2006) mengatakan bahwa iklim merupakan kualitas dari lingkungan (kelas) yang terus menerus dialami oleh dosen-dosen, mempengaruhi tingkah laku, dan berdasar pada persepsi kolektif tingkah laku mereka. Selanjutnya, Hoy dan Miskell dalam Trisetiyanto (2013) menambahkan bahwa istilah iklim seperti halnya kepribadian pada manusia. Artinya, masing-masing kelas mempunyai ciri (kepribadian) yang tidak sama dengan kelas-kelas yang lain, meskipun kelas itu dibangun dengan fisik dan bentuk atau arsitektur yang sama. Moos (1979) juga menambahkan bahwa iklim kelas seperti halnya manusia, ada yang sangat berorientasi pada tugas, demokratis, formal, terbuka, atau tertutup.

Merujuk pada penelitian terdahulu yang telah dilakukan oleh Adi Nova Trisetiyanto (2013) iklim belajar dalam konteks ini digunakan untuk mewakili kata-kata seperti iklim kampus, iklim kelas, lingkungan belajar dan sebagainya. Iklim belajar juga disebut sebagai iklim kerja yang menggambarkan suasana dan hubungan kerja antara sesama dosen, antara dosen dengan pimpinan dan antara dosen dengan mahasiswa di lingkungannya merupakan wujud dari lingkungan kerja yang kondusif. Suasana seperti ini sangat dibutuhkan dosen untuk melaksanakan pekerjaannya dengan lebih efektif agar mampu membimbing para mahasiswa untuk mengembangkan kemampuan mahasiswa dalam hal pembelajaran menggunakan model pembelajaran jatidiri bangsa.

\section{Jatidiri Bangsa}

Jatidiri menurut Kamus Besar Bahasa Indonesia (KBBI) merupakan ciri-ciri, gambaran, atau keadaan khusus seseorang atau suatu benda, bisa pula berarti identitas, inti, jiwa, semangat, dan daya gerak dari dalam atau spiritualitas. Pengertian tersebut memberikan sebuah gambaran bahwa jatidiri merupakan proses belajar mengenal diri sendiri secara lebih mendalam dan mengenal potensi yang dimilikinya. Ketika seseorang telah mengenal dirinya sendiri dan potensinya sendiri, tentu dia akan memiliki sifat kecintaan terhadap lingkungan tempatnya dilahirkan yang menjadikan dia mempunya potensi. Proses pengenalan diri sendiri, potensi dan proses pengenalan lingkungan sekitar akan membawa seseorang kepada suatu fase dimana orang tersebut akan memiliki benih-benih cinta terhadap lingkungannya. Menurut Cogan (1998:2-3) Citizenship “...A sense of identity; the enjoyment of certains rights; the fulfilment of corresponding obligations; a degree of interest and involvement in public affairs; and acceptance of basic societal values".

Pendapat Cogan tersebut diatas mengartikan bahwa secara konseptual seorang warganegara seyogyaya memiliki lima ciri utama, yaitu: jatidiri; kebebasan untuk menikmati hak tertentu; pemenuhan kewajibankewajiban terkait; tingkat minat dan keterlibatan dalam urusan publik; dan pemilikan nilai-nilai dasar 
kemasyarakatan. Ciri utama warganegara tersebut sudah tercantum dalam Pancasila yang merupakan landasan dan pandangan hidup bangsa Indonesia. Menurut pandangan tersebut, salah satu dari lima ciri utama warganegara adalah jatidiri. Masyarakat adalah mereka yang mempunyai jatidiri sesuai dengan dimana ia dilahirkan. Jika dilahirkan di Indonesia, sudah barang tentu masyarakat tersebut berjatidiri bangsa Indonesia.

Jatidiri bangsa merupakan sesuatu hal yang penting bagi semua bangsa di dunia dalam pergaulan internasional. Jatidiri bangsa merupakan identitas bagi sebuah bangsa untuk menentukan pandangan politik luar negeri, politik dalam negeri, pondasi untuk menentukan keputusan-keputusan yang pada hakikatnya untuk membangun kemakmuran dan kesejahteraan bangsa tersebut, dan menjadi keunikan bagi sebuah bangsa. Proses pengenalan jatidiri membutuhkan pendalaman untuk mengenali apa, siapa, dimana, mengapa dan bagaimana diri kita. Begitu pun bagi sebuah bangsa, proses pengenalan jatidiri bangsa perlu dilakukan dengan berbagai macam cara. Salah satu cara yang dapat dilakukan adalah dengan model pembelajaran jatidiri bangsa.

Menurut Gelisli (2015:486) National identity and nation are complicated structures consisting of interrelated ethnical, cultural, territorial, economical and officialpolitical. Menurut pandangannya, jatidiri bangsa atau dalam bahasa Inggris National Identity merupakan struktur rumit yang terdiri dari etnis yang saling terkait, budaya, teritorial, ekonomi dan pejabat politik.
Sepanjang sejarah, semua negara memiliki banyak fitur yang membedakan mereka dari bangsabangsa lain. Semua fitur khas bangsa membentuk konsep "identitas nasional". Bahasa, agama, bendera, sejarah, tanah air, negara, gaya hidup, arsitektur, musik tradisional, adat istiadat, tradisi, sopan santun adalah elemen utama yang merupakan identitas nasional (Eker dalam Gelisli (2015:487).

Jatidiri bangsa dalam penelitian ini mengarahkan perhatiannya pada Pancasila sebagai muara atau goalsnya. Jatidiri bangsa berdasarkan Pancasila adalah karakter atau kepribadian manusia Indonesia yang sikap dan perilakunya mencerminkan nilai KeTuhanan (religius), Kemanusiaan (manusiawi), Persatuan (nasionalis), Kerakyatan (demokratis) dan Keadilan (adil) sehingga dengan sikap dan perilaku tersebut menunjukkan identitas kita sebagai sebuah bangsa dan selanjutnya memunculkan keunikan kita manakala berhubungan dengan bangsa lain (Winarno, 2011:416). Jatidiri bangsa berdasarkan Pancasila yang dimaksud disini juga adalah kepribadian manusia Indonesia yang mampu menghargai perbedaan, sadar akan toleransi, mau bergotongroyong, dan menghargai sejarah.

Dalam literatur kontemporer, Smith dalam Elena (2016:460) menempatkan asal-usul negaranegara modern dalam budaya pramodern (ethnies) dan menggarisbawahi bahwa negara muncul dari kelompok etnis yang sudah ada sebelumnya. Smith menganggap bahwa setiap kelompok etnis harus memiliki, setidaknya, mitos dari nenek moyang yang sama, kenangan sejarah bersama, nama kolektif, dan hubungan dengan 
wilayah tertentu. Smith melihat simbol bermain sangat penting untuk identitas. Identitas nasional dibangun melalui drama sosial tertentu dan peristiwa di mana arti bangsa yang dilombakan dan berpotensi berubah.

Model pembelajaran jatidiri bangsa mengenalkan kepada mahasiswa tentang pentingnya sejarah perjuangan bangsa Indonesia pada masa lalu, tentang banyaknya suku bangsa dan budaya, tentang Indonesia kontemporer untuk mencoba mengingatkan dan memberikan semangat kepada mahasiswa agar tumbuh rasa kecintaan terhadap Indonesia dalam dirinya. Pentingnya model pembelajaran jatidiri bangsa perlu mendapat perhatian dari Kemenristekdikti agar praktekpraktek yang dapat mengurangi rasa kebangsaan bisa diminimalisir. Dewasa ini, perhatian mahasiswa terhadap adanya keberagaman di Indonesia mulai dipertanyakan. Banyaknya kegiatan kemahasiswaan baik internal maupun eksternal hanya memfokuskan pada pembelajaran politik dalam artian sempit. Dimata mahasiswa pemahaman politik hanyalah praktek untuk merebut dan mempertahankan kekuasaan. Oleh karena itu praktek-praktek untuk melanggengkan kekuasaan baik secara legal maupun ilegal kerap dipertontonkan oleh mahasiswa.

Kegiatan seperti diatas dapat mengurangi rasa kebersamaan dan saling ketidakpercayaan terhadap orang lain sehingga mahasiswa lupa kepada jatidiri bangsa Indonesia yang berbeda tapi tetap satu. Praktik tersebut membuat rasa kecintaan terhadap Indonesia semakin terkikis pada diri mahasiswa. Oleh karena itu diperlukan sebuah implementasi model pembelajaran jatidiri bangsa dalam kegiatan pendidikan di perguruan tinggi.

Sesuai dengan tujuannya, model pembelajaran jatidiri bangsa mempunyai karakteristik yang terbangun dalam orientasi konstruktifnya. Orientasi konstruktif model pembelajaran jatidiri bangsa bercirikan bahwa model ini berupaya untuk membantu para pembelajar untuk membangun pengetahuan, keterampilan dan nilai-nilai yang diharapkan muncul ketika mempelajari sesuatu materi.

Model pembelajaran jatidiri bangsa mulai dikembangkan pada tahun 2015 di Universitas Buana Perjuangan (UBP) Karawang sebagai bagian daripada matakuliah Jatidiri Bangsa. Model pembelajaran jatidiri bangsa yang selama ini dikembangkan di UBP Karawang belumlah seratus persen $(100 \%)$ disebut sebagai model pembelajaran yang mampu disebarluaskan ke seluruh Perguruan Tinggi di Indonesia. Hal ini dikarenakan masih perlunya pengembangan dan evaluasi serta perlunya mendapatkan masukan dari para ahli dalam bidang model pembelajaran.

\section{REFERENSI}

Aulia. (2012). Pengertian Pendidikan Kewarganegaraan. Diakses dari http://ekiblogger.blogspot.com/2012/0 5/pengertian-pendidikankewarganegaraan.html [Diakses 27 Desember 2018]

Cogan, J.J. dan Derricott, R. (1998). Citizenship For The 21 Century: An International Perspective On Education. London: Kogan Page.

Gelisli, Yucel. (2015). Opinions of the university students studying in Kazakhstan about 
national identity. Procedia -

Social and Behavioral

Sciences, 197 (2015) 486 493.

Muhadjir N. (2002). Metodologi Penelitian Kualitatif Edisi IV. Yogyakarta : Rake Sarasin.

Sapriya. (2011). Teori \& Landasan Pendidikan

Kewarganegaraan. Bandung: Alfabeta.

Somantri, N. (2001). Mengggas Pembaharuan Pendidikan IPS. Bandung: PT Remaja Rosdakarya.

Trisetiyanto, A. (2013) Iklim Belajar. Diakses dari http://adinovatrisetiyanto.blog spot.com/2013/09/iklimbelajar.html [Diakses 27 Desember 2018]

UU No. 20 tahun 2003 Tentang Sistem Pendidikan Nasional

Winarno. (2011). Implementasi Pancasila Melalui Pendidikan Kewarganegaraan Sebagai Upaya Mengembangkan Jatidiri Bangsa. Disertasi, Sekolah Pascasarjana, Universitas Pendidikan Indonesia. 